\title{
Selective phosphodiesterase inhibitors modulate the activity of alve- olar macrophages from sensitized guinea-pigs
}

\author{
N. Germain*, B. Bertin+, A. Legendre*, B. Martin+, V. Lagente*, A. Payne+, E. Boichot*
}

Selective phosphodiesterase inhibitors modulate the activity of alveolar macrophages from sensitized guinea-pigs. N. Germain, B. Bertin, A. Legendre, B. Martin, V. Lagente, A. Payne, E. Boichot. @ERS Journals Ltd 1998.

ABSTRACT: The aim of this study was to investigate the effects of selective phosphodiesterase (PDE)3 and PDE4 inhibitors on arachidonate release by alveolar macrophages from sensitized and challenged guinea-pigs.

Guinea-pigs were sensitized and challenged with ovalbumin administered by aerosol. Bronchoalveolar lavage was performed 48 h later and the PDE and cyclic adenosine monophosphate (cAMP) contents of or the arachidonate release from alveolar macrophages, stimulated in vitro with $N$-formyl-Met-Leu-Phe (fMLP), were evaluated.

PDE3 and PDE4 activities were detected in preparations of macrophage lysate from sensitized challenged and sensitized control animals. Oral pretreatment, prior to antigen challenge in sensitized guinea-pigs, with rolipram or Ro 20-1724 (PDE4 inhibitors) but not milrinone (PDE3 inhibitor) significantly reduced the arachidonate release from alveolar macrophages. In vitro incubation of alveolar macrophages from challenged guinea-pigs with Ro 20-1724 or the cAMP analogue dibutyryl cAMP (dbcAMP) but not milrinone or the cyclic guanosine monophosphate (cGMP) analogue 8bromo-cGMP (8-br-cGMP) significantly reduced arachidonate release. Incubation of the cells with a combination of milrinone plus rolipram or Ro 20-1724 elicited a marked and significant reduction in arachidonate release by alveolar macrophages stimulated with fMLP.

In conclusion, these data show that phosphodiesterase-4 isoenzyme may regulate the release of inflammatory mediators such as arachidonate from macrophages through an increase in intracellular cyclic adenosine monophosphate. This suggests that phosphodiesterase-4 inhibitors have potential in the treatment of inflammatory disorders of the lung.

Eur Respir J 1998; 12: 1334-1339.
*INSERM U456, Laboratoire de Pharmacodynamie et de Pharmacologie Moléculaire, Faculté des Sciences Pharmaceutiques et Biologiques, Université de Rennes 1, Rennes, France. +Institut de Recherche Jouveinal, Fresnes, France.

Correspondence: E. Boichot INSERM U456

Laboratoire de Pharmacodynamie et de

Pharmacologie Moléculaire

Faculté des Sciences Pharmaceutiques et Biologiques

Université de Rennes 1

2 avenue du Pr. Léon Bernard

35043 Rennes cedex

France

Fax: 33299336242

Keywords: Alveolar macrophage guinea-pig

selective phosphodiesterase inhibitor

Received: March 31998

Accepted after revision August 61998
The cyclic nucleotides cyclic adenosine monophosphate (cAMP) and cyclic guanosine monophosphate (cGMP) are important second messengers in cell function. The concentration of intracellular cAMP increases either as a consequence of receptor-triggered adenylyl cyclase activation or by decreased activity of phosphodiesterase (PDE), which regulates the breakdown of cAMP and cGMP. PDE are a growing group of enzymes, classified into seven distinct families (PDE1-PDE7) with several subtypes and splice variants (for recent reviews, see [1, 2]). Among them, PDE3, PDE4 and PDE7 appear to be the most important in the regulation of cAMP. In the majority of inflammatory cells, the low Michaelis constant $(k \mathrm{M}) \mathrm{cAMP}$-specific members of the PDE4 family are the most prominently expressed and, thus, have attracted attention as a pharmacological target in the field of inflammatory drug development [3-5]. Selective PDE4 inhibitors such as rolipram and Ro 20-1724 have been shown to inhibit several leukocyte functions, including inflammatory mediatorrelease [5].

In mononuclear cells, PDE3 is also involved in the regulation of cAMP levels. Indeed, the selective PDE3 inhibitor milrinone elicits a moderate inhibition of arachidonate release from these cells [6] and appears to synergize with inhibitors of PDE4 to reduce proliferation [7]. In macrophages, in the presence of the adenylyl cyclase activator, prostaglandin E2 (PGE2), PDE3 inhibitors are as effective as PDE4-selective drugs in the inhibition of tumour necrosis factor- $\alpha$ release [8]. Therefore, HatZeLMANN et al. [9] proposed that PDE3-PDE4 synergism may reduce the risk of side-effects caused by each selective inhibitor alone, since it is plausible that the required doses of dual inhi-bitors of PDE3 and PDE4 isoenzymes will be markedly lower than those of selective inhibitors alone.

Alveolar macrophages play a major role in lung defence. In addition, they are the main cell type involved in the tissue injury associated with inflammatory disease in the lung, including asthma and acute respiratory distress syndrome (for review, see [10]). Indeed, alveolar macrophages are able to release several inflammatory mediators, including cytokines, growth factor and arachidonic acid metabolites, in various pathophysiological situations (for review, see [11]). Bronchial hyperresponsiveness is associated with enhanced activity of alveolar macrophages collected from sensitized and antigen-challenged guineapigs or naive guinea-pigs exposed to an aerosol of substance P $[12,13]$. 
The present study was undertaken in order to investigate the effects of selective PDE3 and PDE4 inhibitors on arachidonate release by alveolar macrophages from sensitized and challenged guinea-pigs. Moreover, the in-volvement of intracellular cAMP was analysed and the cAMPPDE isoenzyme activity profile in these cells identified.

\section{Materials and methods}

\section{Materials}

The following drugs were used: bovine serum albumin (BSA), $N$-formyl-Met-Leu-Phe (fMLP), 3-isobutyl-1-methylxanthine (IBMX), ethylenediaminetetra-acetic acid (EDTA), ovalbumin (OA; chicken egg, grade $\mathrm{V}$ ), milrinone, $N^{6}, 2^{2}-$ $O$-dibutyryladenosine 3 ',5'-cyclic monophosphate (db-cAMP), 8-bromoguanosine 3',5'-cyclic monophosphate (8-br-cGMP), tris-hydroxymethyl-amino methane (Tris), $\mathrm{MgCl} 2$, dithiothreitol, aprotinin, benzamidine, soybean trypsin inhibitor and bacitracin were obtained from Sigma (St Louis, MO, USA); racemic rolipram was synthesized at the Institut de Recherche Jouveinal Fresnes, France; Ro 20-1724 was from RBI (Natick, MA, USA); phosphate-buffered saline (PBS) was from Gibco (Cergy-Pontoise, France); ${ }^{3} \mathrm{H}$-arachidonic acid was from Amersham (Les Ulis, France); urethane (ethylcarbamate) was from Prolabo (Gradignan, France); ${ }^{3} \mathrm{H}$-AMP and ${ }^{3} \mathrm{H}$-cGMP were from Dupont de Nemours; and trichloroacetic acid (TCA) was obtained from Merck (Darmstadt, Germany).

\section{Sensitization procedure and challenge}

Pathogen-free male Hartley guinea-pigs (300-350 g; Charles River, St Aubin les Elboeuf, France) were used throughout the study. Guinea-pigs were sensitized and challenged as described previously [14]. In brief, they were placed in a Plexiglass chamber $(30 \times 50 \times 30 \mathrm{~cm})$ and exposed twice for $30 \mathrm{~min}$ to an aerosol of $2 \mathrm{mg} \cdot \mathrm{mL}^{-1} \mathrm{OA}$ in saline $(\mathrm{NaCl}, 0.9 \%)$, at an interval of $48 \mathrm{~h}$. The aerosol was generated by a Devilbiss ultrasonic nebulizer (ULTRANEB 99; Somerset, PA, USA). At 15-20 days after the initial sensitization procedure, the guinea-pigs were challenged by exposure to five successive concentrations of OA: $10 \mu \mathrm{g} \cdot \mathrm{mL}^{-1}, 100 \mu \mathrm{g} \cdot \mathrm{mL}^{-1}, 1 \mathrm{mg} \cdot \mathrm{mL}^{-1}, 5 \mathrm{mg} \cdot \mathrm{mL}^{-1}$ and $10 \mathrm{mg} \cdot \mathrm{mL}^{-1}$ for $15 \mathrm{~min}$ each. Control guinea-pigs were exposed to a saline solution for an equivalent period.

\section{Bronchoalveolar lavage}

Bronchoalveolar lavage (BAL) was performed $48 \mathrm{~h}$ after OA challenge. Guinea-pigs were anaesthetized with urethane $\left(1.2 \mathrm{~g} \cdot \mathrm{kg}^{-1}\right.$, i.p. $)$, the trachea was cannulated and 5 $\mathrm{mL}$ of a saline solution $\left(37^{\circ} \mathrm{C}\right)$ containing $2.6 \mathrm{mM}$ EDTA was instilled into the lungs with a $5-\mathrm{mL}$ syringe. The lavage fluid was recovered by gentle aspiration. This procedure was repeated 10 times and the fluids were combined. Total fluid recovery was $>85 \%$ of the injected volume. The lavage fluid was adjusted to $50 \mathrm{~mL}$ with PBS. After centrifugation at $350 \times g$ for $10 \mathrm{~min}$, the cell pellet was resuspended in $10 \mathrm{~mL}$ PBS. Total cell counts were determined on Malassez chambers (Poly Labo, Strasbourg, France) by means of optical microscopy.

\section{Isolation and identification of phosphodiesterase}

Freshly prepared alveolar macrophages were isolated, after adhesion on plastic Petri dishes for $60 \mathrm{~min}$ at $37^{\circ} \mathrm{C}$, resuspended in buffer containing $10 \mathrm{mM}$ Tris, $1 \mathrm{mM} \mathrm{MgCl}$, $1 \mathrm{mM}$ dithiothreitol, $2 \mathrm{U} \cdot \mathrm{mL}^{-1}$ aprotinin, $\mathrm{pH} 7.5$, and sonicated using a Labsonic sonicator (Bomem/Hartmann et Braun, Quebec, QC, Canada). After centrifugation at 40,000 $\times g$ for $30 \mathrm{~min}$, the supernatant was frozen at $-20^{\circ} \mathrm{C}$ for subsequent purification of isoenzymes. PDE isoenzyme separation was performed according to the method of LaVAN et al. [15] using anion-exchange (Mono-Q; Pharmacia Biotech, Saclay, France) column chromatography in association with fast protein liquid chromatography (FPLC; Biocad; Perspective Biosystem, Perkin Elmer, Norwalk, CT, USA). The column was equilibrated with a $60-\mathrm{mL}$ bed volume of buffer containing $20 \mathrm{mM}$ bis-Tris, pH $6.5,10 \mathrm{mM}$ EDTA, $2.5 \mathrm{mM}$ dithiothreitol and a protease inhibitor mixture containing $2 \mathrm{mM}$ benzamidine, 2 $\mu \mathrm{g} \cdot \mathrm{mL}^{-1}$ soybean trypsin inhibitor, $100 \mu \mathrm{g} \cdot \mathrm{mL}^{-1}$ bacitracin and $50 \mu \mathrm{M}$ phenylmethylsulphonyl fluoride (PMSF). Enzyme extracts were loaded on the column, eluted with 100 $\mathrm{mL}$ of a linear $(0-1 \mathrm{M}) \mathrm{NaCl}$ gradient and $1.5-\mathrm{mL}$ fractions collected over the entire gradient. To stabilize the enzyme, $0.1 \mathrm{mg}$ BSA was added to each fraction. The activities of individual PDE isoenzymes were determined in 96-well microplates using $0.1 \mu \mathrm{M}$ cAMP and $74 \mathrm{kBq}$. $\mathrm{mL}^{-1}\left(2 \mu \mathrm{Ci} \cdot \mathrm{mL}^{-1}\right){ }^{3} \mathrm{H}$-cAMP in $40 \mathrm{mM}$ Tris- $\mathrm{HCl}, 5 \mathrm{mM}$ $\mathrm{MgCl}_{2}, 4 \mathrm{mM}$ 2-mercaptoethanol in distilled water. All fractions were assayed in the absence or presence of 30 $\mu \mathrm{M}$ rolipram or SKF 94836. The reaction was stopped with $25 \mu 0.4 \%$ TCA and the entire fraction was transferred into 96-well plates (Loprodyne; Pall Filtron, Saint Germain en Laye, France) containing $50 \mathrm{mg} \mathrm{Al}(\mathrm{OH})_{3} .{ }^{3} \mathrm{H}-$ AMP was separated from ${ }^{3} \mathrm{H}-\mathrm{cAMP}$ with $\mathrm{AL}(\mathrm{OH})_{3}$ after elution with $1 \mathrm{M} \mathrm{NaOH}$. The results are expressed as counts per minute (cpm) of PDE activity in each fraction.

\section{Measurement of cyclic adenosine monophosphate levels}

Alveolar macrophages were distributed in 12-well plates (Falcon, Le Pont de Claix, France) (at $1.5 \times 10^{6}$ cells $\cdot$ well $^{-1}$ ) and allowed a stabilization time of $60 \mathrm{~min}$ at $37^{\circ} \mathrm{C}$ in the presence of $5 \%$ foetal serum cell (FCS), followed by 60 min at $37^{\circ} \mathrm{C}$ without FCS. In some experiments, the cells were incubated at $37^{\circ} \mathrm{C}$ for 20 min with $200 \mu \mathrm{M}$ IMBX. The reactions were stopped by the addition of $0.5 \mathrm{~mL} 0.1$ $\mathrm{N} \mathrm{HCl}$ at $4{ }^{\circ} \mathrm{C}$. The supernatant was immediately frozen at $-80^{\circ} \mathrm{C}$ until cAMP determinations could be performed. The levels of cAMP were determined by radioimmunoassay using 125I-cAMP (RIANEN; Dupont, Wilmington, USA).

\section{Protocol}

In the first set of experiments, guinea-pigs were treated orally with rolipram $\left(3 \mathrm{mg} \cdot \mathrm{kg}^{-1}\right)$, Ro $20-1724\left(30 \mathrm{mg} \cdot \mathrm{kg}^{-1}\right)$ or milrinone $\left(30 \mathrm{mg} \cdot \mathrm{kg}^{-1}\right), 24 \mathrm{~h}$ and $3 \mathrm{~h}$ before OA challenge. The protocol and doses of selective PDE inhibitors used have previously been shown to be effective in the reduction of recruitment of eosinophils in sensitized guineapigs [16]. 
In the second set of experiments, alveolar macrophages from sensitized challenged or sensitized control guineapigs were incubated in vitro for $30 \mathrm{~min}$ with rolipram (10 $\mu \mathrm{M})$, Ro 20-1724 (10 $\mu \mathrm{M})$, milrinone $(10 \mu \mathrm{M})$, db-cAMP $(1 \mathrm{mM})$ or 8-br-cGMP $(1 \mathrm{mM})$. These concentrations of selective PDE inhibitors have previously been shown to be effective in the reduction of arachidonate release from human mononuclear cells [6].

\section{Alveolar macrophage activation and arachidonate release}

Alveolar macrophages were separated by adherence, for $1 \mathrm{~h}$ at $37^{\circ} \mathrm{C}$, to plastic Petri dishes $\left(2 \times 10^{6}\right.$ cells $2 \mathrm{~mL}^{-1} \cdot 35$ mm.dish ${ }^{-1}$ (Falcon)) in an atmosphere of $5 \% \mathrm{CO}_{2}$ and $100 \%$ humidity. For arachidonic acid incorporation, macrophages were labelled with ${ }^{3} \mathrm{H}$-arachidonic acid $(22 \mathrm{kBq}$ $(0.6 \mu \mathrm{Ci}) \cdot 2 \times 10^{6}$ cells $\left.^{-1}\right)$. One hour later, the supernatant was discarded and the cells were washed three times with PBS containing $0.2 \%$ BSA. After 30 min resting times, macrophages were stimulated with $1 \mu \mathrm{M}$ fMLP for $10 \mathrm{~min}$. For the in vitro protocol, macrophages were incubated with various compounds for $30 \mathrm{~min}$ and then stimulated with $1 \mu \mathrm{M}$ fMLP for $10 \mathrm{~min}$. Samples were then centrifuged for $3 \mathrm{~min}$ at $1,250 \times \mathrm{g}, 0.4 \mathrm{~mL}$ of supernatant was added to $2 \mathrm{~mL}$ of scintillation cocktail (Packard Instrument, Meriden, CT, USA) in Pico vials (Packard Instrument) and samples were counted in a liquid scintillation analyser (Packard Instrument).

\section{Data analysis}

Release of ${ }^{3} \mathrm{H}$-arachidonate was expressed as a percentage of the cpm recovered in the supernatant compared to the control values (cells without stimulation by fMLP). Results are expressed as means \pm SEM. For the cAMP levels, the results are expressed as means (fM $\cdot 10^{6}$ cells $\left.^{-1}\right) \pm$ SEM. Analyses for statistical significance were performed using the nonparametric Mann-Whitney U-test.

\section{Results}

Characterization of cyclic adenosine monophosphate dependent phosphodiesterase activity in alveolar macrophages

To identify the cAMP-dependent PDE isoenzymes present in alveolar macrophages from sensitized guineapigs, supernatants of cell lysates were applied to an anion exchange column and the PDE activity eluted with a linear $\mathrm{NaCl}$ gradient. A broad peak of PDE activity eluting between 400 and $650 \mathrm{mM} \mathrm{NaCl}$ was noted in alveolar macrophages from both saline-exposed (fig. 1a) and OAchallenged (fig. 1b) sensitized guinea-pigs. Two peaks of PDE4 activity, at $450-500 \mathrm{mM}$ and at $525-550 \mathrm{mM} \mathrm{NaCl}$, were detected in both preparations, as shown by the marked inhibitory activity of $30 \mu \mathrm{M}$ rolipram (fig. $1 \mathrm{a}$ and b). Similarly, a peak of PDE3 activity was noted at 625-650 $\mathrm{mM} \mathrm{NaCl}$, as demonstrated by the inhibitory activity of 30 $\mu \mathrm{M}$ SKF 94836. No marked difference in cAMP-hydrolysing PDE activity was found between saline-ex-posed and OA-challenged guinea-pigs (fig. 1a and b).
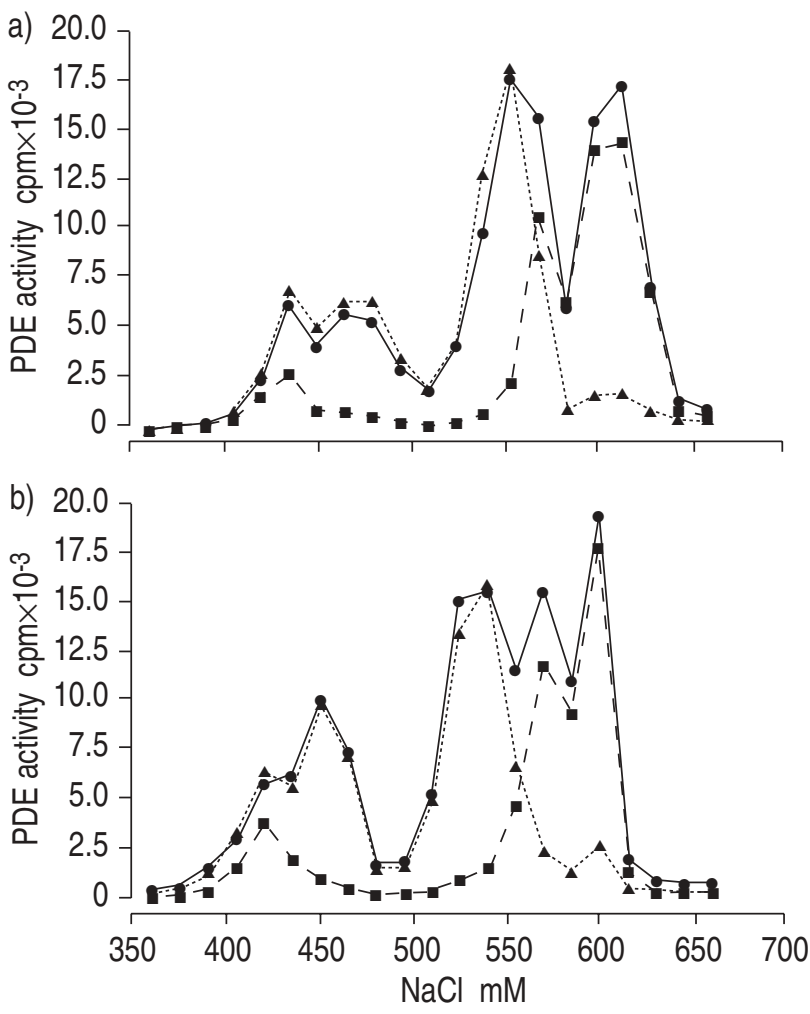

Fig. 1. - Elution profile of cyclic adenosine monophosphate (cAMP)dependent phosphodiesterase (PDE) activity of guinea-pig alveolar macrophages. Alveolar macrophages were collected from a) saline-exposed or b) ovalbumin (OA)-challenged, sensitized guinea-pigs. The macrophages were lysed and the supernatant fraction was applied to an anionexchange column. The protein was eluted with a linear $\mathrm{NaCl}$ gradient containing $0.1 \mathrm{mM}$ cAMP (control; •); $30 \mu \mathrm{M}$ rolipram $(\mathbf{\square})$; or $30 \mu \mathrm{M}$ SK\&F 94836 (४). cpm: counts per minute.

Effect of ovalbumin challenge on intracellular cyclic adenosine monophosphate levels in alveolar macrophages

The levels of cAMP were evaluated $1 \mathrm{~h}$ and $48 \mathrm{~h}$ following exposure of sensitized guinea-pigs to either saline or OA. No significant change in cAMP levels was noted in alveolar macrophages incubated with or without $200 \mu \mathrm{M}$ IBMX, $1 \mathrm{~h}$ after challenge in both groups of guinea-pigs (fig. 2). In contrast, at $48 \mathrm{~h}$, a marked and significant increase in the intracellular level of cAMP was observed in macrophages from OA-challenged guinea-pigs compared with the cells from control guinea-pigs (fig. 2). The changes in cAMP levels were also observed after incubation of alveolar macrophages with $200 \mu \mathrm{M}$ IBMX. In these conditions the level of cAMP was considerably elevated at $48 \mathrm{~h}$, particularly in alveolar macrophages from OA-challenged guinea-pigs (fig. 2).

Effect of oral treatment with phosphodiesterase inhibitors on arachidonate release from alveolar macrophages after ovalbumin challenge in aerosol-sensitized guinea-pigs

OA challenge in aerosol-sensitized guinea-pigs elicited a marked and significant increase in arachidonate release from alveolar macrophages stimulated in vitro with (1 $\mu \mathrm{M}$ ) fMLP (figs. 3 and 4). Pretreatment at $24 \mathrm{~h}$ and $3 \mathrm{~h}$ 


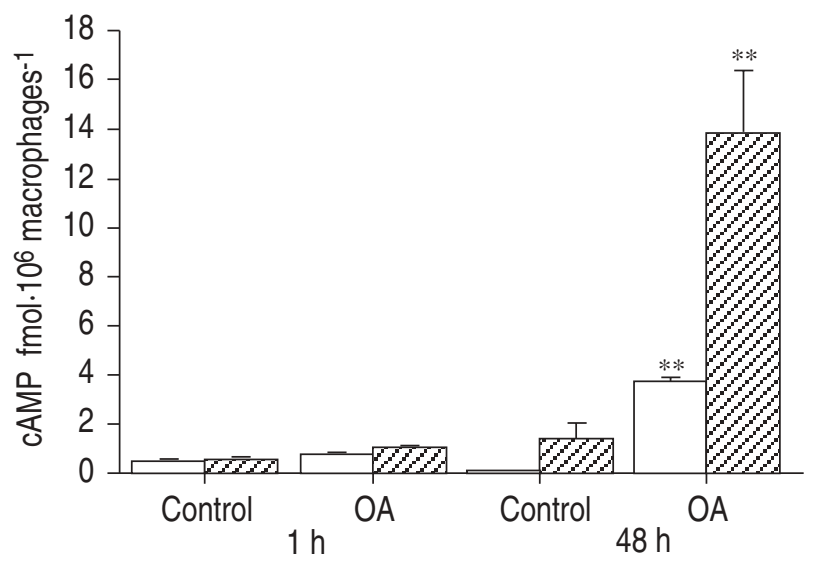

Fig. 2. - Intracellular cyclic adenosine monophosphate (cAMP) levels of alveolar macrophages from sensitized guinea-pigs, $1 \mathrm{~h}$ or $48 \mathrm{~h}$ following saline-exposure (control) or ovalbumin (OA) challenge. In some experiments, the cells were incubated with $200 \mu \mathrm{M}$ 3-isobutyl-1-methylxanthine (IBMX; $Z 2$ ). The results are expressed in fmol of cAMP in $10^{6}$ macrophages \pm SEM. $* *: \mathrm{p}<0.01$ compared with control $(\mathrm{n}=6-7)$.

before OA challenge with rolipram $\left(3 \mathrm{mg} \cdot \mathrm{kg}^{-1}\right)$ or Ro $20-1724\left(30 \mathrm{mg} \cdot \mathrm{kg}^{-1}\right)$ significantly reduced the increase in arachidonate release after in vitro stimulation of the macrophages with fMLP. No significant changes in the arachidonate release were noted in saline-exposed guineapigs treated with either rolipram or Ro 20-1724. Pretreatment of OA-challenged guinea-pigs with milrinone (30 $\left.\mathrm{mg} \cdot \mathrm{kg}^{-1}\right)$ moderately but nonsignificantly reduced the fMLP-induc-ed arachidonate release (fig. 3).

Effect of in vitro incubation with phosphodiesterase inhibitors on arachidonate release from alveolar macrophages from sensitized guinea-pigs

No significant inhibition of fMLP-induced arachidonate release from alveolar macrophages collected from salineexposed guinea-pigs was noted upon in vitro incubation of

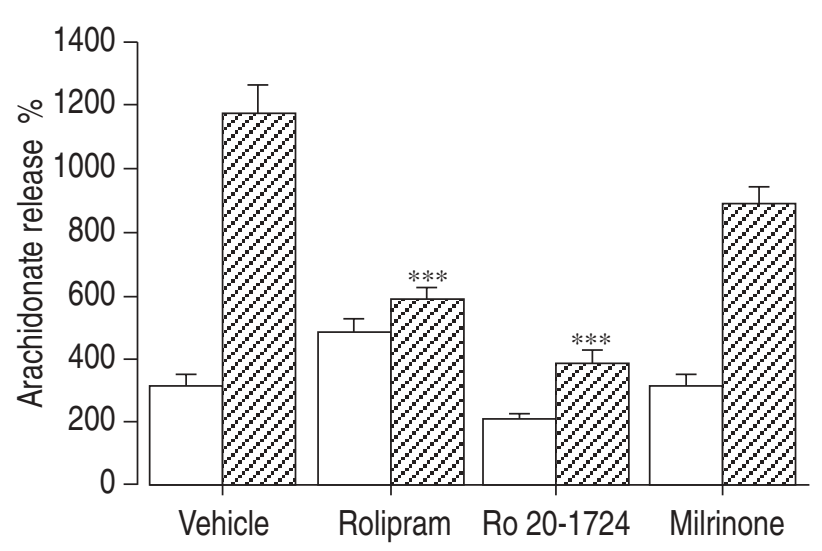

Fig. 3. - Effect of the selective phosphodiesterase-4 (PDE4) inhibitors rolipram (3 $\left.\mathrm{mg} \cdot \mathrm{kg}^{-1}\right)$ and Ro 20-1724 (30 mg. $\left.\mathrm{kg}^{-1}\right)$ and the selective PDE3 inhibitor milrinone $\left(30 \mathrm{mg} \cdot \mathrm{kg}^{-1}\right)$ on arachidonate release by $\mathrm{N}$ formyl-Met-Leu-Phe (fMLP)-stimulated alveolar macrophages collected from saline-exposed ( $\square$ ) or ovalbumin (OA)-challenged ( $Q$ ) sensitized guinea-pigs. Guinea-pigs were treated orally with PDE inhibitors $24 \mathrm{~h}$ and $3 \mathrm{~h}$ before challenge and the alveolar macrophages were collected at $48 \mathrm{~h}$. Results are expressed as means (percentage of release) of arachidonate \pm SEM. $* * *: \mathrm{p}<0.001$ compared with vehicle $(\mathrm{n}=6-7)$.

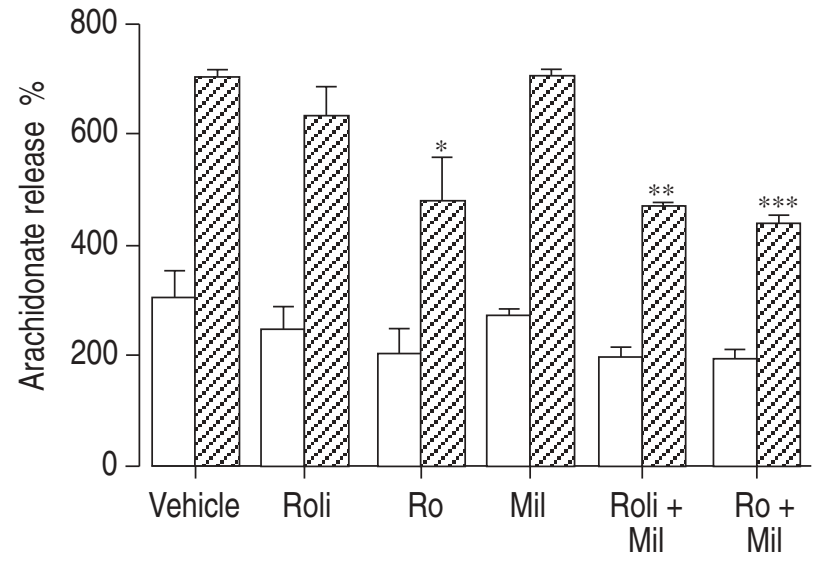

Fig. 4. - Effect of the selective phosphodiesterase-4 (PDE4) inhibitors rolipram (Roli; $10^{-5} \mathrm{M}$ ) and Ro 20-1724 (Ro; $\left.10^{-5} \mathrm{M}\right)$, and the selective PDE3 inhibitor milrinone (Mil $10^{-5} \mathrm{M}$ ) and their combinations on the arachidonate release by $\mathrm{N}$-formyl-Met-Leu-Phe (fMLP)-stimulated alveolar macrophages collected from saline-exposed ( $\square$ ) or ovalbumin $(\mathrm{OA})$-challenged ( 2 ) sensitized guinea-pigs. Alveolar macrophages were collected at $48 \mathrm{~h}$ following challenge and incubated in vitro for 30 min with the compounds. Results are expressed as means (percentage of release) of arachidonate \pm SEM from four experiments performed in triplicate. $*$ : $\mathrm{p}<0.05 ; * *: \mathrm{p}<0.01 ; * * *: \mathrm{p}<0.001$ compared with vehicle.

the cells with the PDE inhibitors rolipram, Ro 20-1724 or milrinone, the cAMP analogue db-cAMP or the cGMP analogue 8-br-cGMP (fig. 4).

Incubation of alveolar macrophages from OA-challenged guinea-pigs with rolipram $\left(10^{-5} \mathrm{M}\right)$ or milrinone $\left(10^{-5}\right.$ $\mathrm{M})$ did not significantly reduce the fMLP-induced increase in arachidonate release from these cells (fig. 4). Ro $20-1724\left(10^{-5} \mathrm{M}\right)$ slightly and significantly reduced arachidonate release.

Incubation of the cells with a combination of milrinone plus rolipram or Ro 20-1724 elicited a significant reduction in fMLP-induced arachidonate release. db-cAMP, but not 8-br-cGMP, moderately but significantly inhibited arachidonate release (fig. 5).

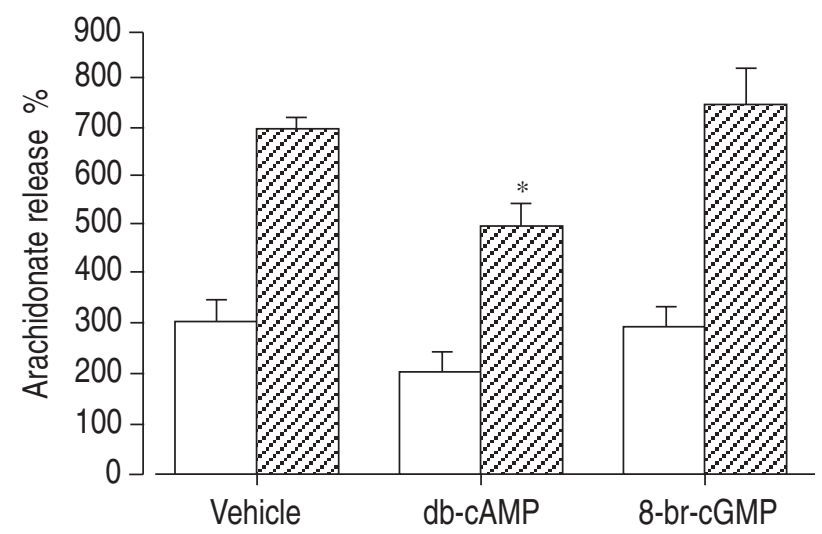

Fig. 5. - Effect of the analogue of cyclic adenosine monophosphate (cAMP) $N^{6}-2^{2}-0$-dibutyryl cAMP (db-cAMP; $10^{-3} \mathrm{M}$ ), and the analogue of cyclic guanosine monophosphate (cGMP), 8-bromo cGMP (8-br-cGMP; $10^{-3} \mathrm{M}$ ), on arachidonate release by $N$-formyl-Met-Leu-Phe (fMLP)stimulated alveolar macrophages collected from saline-exposed ( $\square$ ) or ovalbumin (OA)-challenged ( $Z$ ) sensitized guinea-pigs. Alveolar macrophages were collected $48 \mathrm{~h}$ following challenge and incubated in vitro for $30 \mathrm{~min}$ with the compounds. Results are expressed as means (percentage of release) of arachidonate \pm SEM from four experiments performed in triplicate. *: $\mathrm{p}<0.05$ compared with vehicle. 


\section{Discussion}

Airway hyperresponsiveness induced by OA challenge is generally associated in humans and in experimental animals with an influx of inflammatory cells in lung tissue $[14,17]$ and the activation of resident pulmonary cells such as alveolar macrophages [13, 18, 19]. The present study reports that macrophages recovered in the BAL fluid of either saline-exposed or OA-challenged sensitized guinea- pigs exhibited PDE types 3 and 4 isoenzyme activity. This was clearly observed by the inhibitory activities of the selective PDE4 inhibitor rolipram and the selective PDE3 inhibitor SKF 94836. Therefore, it is suggested that the profile of PDE activities in the macrophage may influence the functional control by PDE inhibitors. This result is consistent with previous studies performed on human ma-crophages, reporting the presence of PDE3 and PDE4 isoenzymes [20,21]. This may be compared with the presence of PDE4 alone in monocytes [21, 22] or in a human monocytic cell line [23]. It has also been reported that the in vitro differentiation of human peripheral blood monocytes into macrophages is characterized by an increase in PDE3 activity, resulting in a PDE isoenzyme profile characteristic of mature macrophages $[8,21]$.

Increased PDE4 activity in peripheral blood monocytes from patients with atopic dermatitis has been reported [24]. If PDE4 induction occurs in inflammatory cells in asthma, possibly in response to pro-inflammatory cytokines [25], this would result in reduced intracellular cAMP levels, leading to increased activity of inflammatory cells [26$28]$. In the present experimental conditions, there were no significant differences in PDE isoenzyme profiles when comparing alveolar macrophages from either saline-exposed or OA-challenged sensitized guinea-pigs. This is consistent with the results obtained by TeNor et al. [21], who reported no difference between alveolar macrophages from normal donors and from atopic asthmatics. Whether the enzyme(s) that are elevated following antigen challenge in sensitized guinea-pigs or in atopic patients are activated or subject to differential inhibition by PDE inhibitors is unknown. For this reason, the level of intracellular cAMP in alveolar macrophages from either saline-exposed or OA-challenged guinea-pigs was investigated.

The present results show that OA challenge induced a sustained increase in intracellular cAMP at $48 \mathrm{~h}$. This enhanced level of intracellular cAMP was seen following incubation of the cells with the nonselective PDE inhibitor IBMX. In contrast, no change was observed at $1 \mathrm{~h}$. These results are consistent with those reported by BEUSENBERG et al. [29], showing an increase in intracellular cAMP level, in alveolar macrophages after OA challenge in sensitized guinea-pigs. The observed rise in cAMP levels dur-ing OA challenge seems to be in contradiction to an expected increase in macrophage activity, since increases in intracellular cAMP levels are generally reflected by a decrease in cellular activity. However, the interaction of proinflammatory mediators, released during OA challenge, such as PGE2, with the adenylyl cyclase system results in a rise in intracellular cAMP levels. Therefore, it is conceivable that a transient and rapid decrease in cAMP levels, allowing the release of mediators, may be followed by a marked and long-lasting enhancement, as observed in the present study.
OA challenge in sensitized guinea-pigs elicits an enhanced activity of alveolar macrophages, as demonstrated by the increased release of superoxide anions [13] or arachidonate after in vitro stimulation by fMLP (present study). The release of arachidonate was significantly reduced upon oral treatment of the guinea-pigs by the selective PDE4 inhibitors rolipram and Ro 20-1724, but not by the selective PDE3 inhibitor milrinone. In agreement with a previous study on the reduced activity of guinea-pig alveolar macrophages by PDE4 inhibitors [30], the present data confirm the potential interest of selective PDE4 inhibitors as anti-inflammatory drugs. It was previously demonstrated that, at the same doses, rolipram and Ro 20-1724 significantly reduced the recruitment of eosinophils in guinea-pigs induced by $\mathrm{OA}$ challenge, platelet-activating factor or interleukin-5 [16, 31]. However, the relationship between the recruitment of granulocytes in BAL and the reactivity of alveolar macrophages is not clear. It might be expected that the presence of granulocytes and cell fragments in the BAL fluid may activate the phagocytic activity of macrophages and, therefore, their ability to release various mediators.

When the alveolar macrophages were collected in the BAL fluid $24 \mathrm{~h}$ after OA challenge, Ro 20-1724 but not rolipram had a significant inhibitory effect, whereas incubation of the cells with the PDE3 inhibitor milrinone did not reduce arachidonate release. These results are not consistent with the previous data obtained on mononuclear cells from healthy subjects [6]. It is not clear why rolipram is ineffective in inhibiting arachidonate release. Indeed, rolipram and Ro 20-1724 elicited a marked and significant inhibition of arachidonate release from mononuclear cells [6] at lower concentrations $\left(10^{-7} \mathrm{M}\right.$ and $10^{-6}$ $M$, respectively) than were used in the present study. Therefore, it is possible that alveolar macrophages are less sensitive than peripheral blood mononuclear cells to PDE4 inhibitors. This sensitivity could be due to the difference in the membrane permeability and/or in the cell's isoenzyme content. Indeed, it is well recognized that monocytes only contain PDE4 isoenzymes, whereas macrophages contain both PDE3 and PDE4 isoenzymes (this study and [8, 21]). This would strongly influence the reactivity of the cells according to their phenotypes. In this regard, the combination of milrinone plus the selective PDE4 inhibitors rolipram or Ro 20-1724 also had a significant inhibitory effect. This suggests that PDE4 plays a role in the control of mediator release from alveolar macrophages and that this control is enhanced when the PDE3 isoenzyme is inhibited.

Finally, in common with previous results in mononuclear cells [18], the cell-permeable analogue of cAMP, $\mathrm{db}$-cAMP, elicited a significant reduction in arachidonate release from macrophages recovered in the BAL fluid of guinea-pigs after OA challenge, whereas the cGMP analogue was ineffective. This represents direct evidence that a selective increase in intracellular cAMP (but not cGMP) reduces arachidonate release. This also suggests that PDE4 and PDE3 inhibitors, which block the breakdown of cAMP by $\mathrm{PDE}$, reduce the arachidonate release, in part, through the cAMP-protein kinase A pathway.

In conclusion, the present data show that the phosphodiesterase- 3 and -4 isoenzymes are present in alveolar macrophages from sensitized guinea-pigs and that phosphodiesterase-4, and to a lesser extent, phosphodiesterase-3, 
regulate the release of inflammatory mediators such as arachidonic acid through an increase in intracellular cyclic adenosine monophosphate levels. However, it seems that the inhibitory activity of phosphodiesterase-4 inhibitors in vivo occurs by interaction with others cells rather than a direct effect on alveolar macrophages. These results also support the potential utility of selective phosphodiesterase inhibitors in the treatment of asthma and other inflammatory disorders of the airways.

\section{References}

1. Beavo JA, Conti M, Heaslip RJ. Multiple cyclic nucleotide phosphodiesterase. Mol Pharmacol 1994; 46: 399-405.

2. Bolger GB. Molecular biology of the cyclic AMP-specific cyclic nucleotide phosphodiesterases: a diverse family of regulatory enzymes. Cell Signalling 1994; 6: 851-859.

3. Banner KH, Page CP. Theophylline and selective phosphodiesterase inhibitors as anti-inflammatory drugs in the treatment of bronchial asthma. Eur Respir J 1995; 8: 996-1000.

4. Nicholson CD, Shahid M. Inhibitors of cyclic nucleotide phosphodiesterase isoenzymes. Their potential utility in the therapy of asthma. Pulm Pharmacol 1994; 6: 1-17.

5. Teixeira MM, Gristwood RW, Cooper N, Hellewell PG. Phosphodiesterase (PDE)4 inhibitors: anti-inflammatory drugs of the future? Trends Pharmacol Sci 1997; 18: 164-171.

6. Hichami A, Boichot E, Germain N, Legrand A, Moodley I, Lagente V. Involvement of cyclic AMP in the effects of phosphodiesterase IV inhibitors on arachidonate release. Eur J Pharmacol 1995; 291: 91-97.

7. Banner KH, Roberts NM, Page CP. Differential effect of phosphodiesterase 4 inhibitors on the proliferation of human peripheral blood mononuclear cells from normals and subjects with atopic dermatitis. Br J Pharmacol 1995; 116: 3169-3174.

8. Gantner F, Kupferschmidt R, Schudt C, Wendel A, Hatzelmann A. In vitro differentiation of human monocytes to macrophages: change of PDE profile and its relationship to suppression of tumor necrosis factor- $\alpha$ release by PDE inhibitors. Br J Pharmacol 1997; 121: 221-231.

9. Hatzelmann A, Engelsädtter R, Morley J, Mazzoni I. Enzymatic and functional aspects of dual selective PDE 3/4 inhibitors. In: Schudt C, Dent G, Rabe KF, eds. Phosphodiesterase Inhibitors. London, Academic Press, 1996; pp. 147-160.

10. Lee TH, Lane SJ. The role of macrophages in the mechanism of airway inflammation in asthma. Am Rev Respir Dis 1992; 145: S27-S30.

11. Lohmann-Mathes ML, Steinmüller C, Franke-Ullman G. Pulmonary macrophages. Eur Respir J 1994; 7: 16781689.

12. Boichot E, Lagente V, Paubert-Braquet M, Frossard N. Inhaled substance $\mathrm{P}$ induces activation of alveolar macrophages and increases airway responses in the guinea-pig. Neuropeptides 1993; 25: 307-313.

13. Lagente V, Boichot E, Chadli S, Dugas B, Mencia-Huerta JM, Braquet P. Effect of the platelet-activating factor antagonist, BN 50730, on the increased production of superoxide anions by alveolar macrophages from antigen-exposed sensitized guinea-pigs. Fund Clin Pharmacol 1991; 5: 426.

14. Boichot E, Lagente V, Carre C, Waltmann P, Mencia-Huerta JM, Braquet P. Bronchial hyperresponsiveness and cellular infiltration in the lung of guinea-pigs sensi- tized and challenged by aerosol. Clin Exp Allergy 1991; 21: 67-76.

15. Lavan BE, Lakey T, Houslay MD. Resolution and soluble cyclic nucleotide phosphodiesterase isoenzymes, from liver and hepatocytes, identifies a novel IBMX-insensitive form. Biochem Pharmacol 1989; 38: 4123-4136.

16. Lagente V, Moodley I, Perrin S, Mottin G, Junien JL. Effects of isozyme-selective phosphodiesterase inhibitors on eosinophil infiltration in the guinea-pig lung. Eur $J$ Pharmacol 1994; 255: 253-256.

17. Holgate ST, Djukanovic R, Wilson J, Roche W, Roche $\mathrm{PH}$, Howarth PH. Inflammatory processes and bronchial hyperresponsiveness. Clin Exp Allergy 1991; 21: Suppl. 1, 30-36.

18. Cluzel M, Damon M, Chanez P, et al. Enhanced alveolar cell luminol dependent chemiluminescence in asthma. $J$ Allergy Clin Immunol 1987; 80: 195-201.

19. Tonnel AB, Cosset P, Joseph M, Fournier E, Capron A. Stimulation of alveolar macrophages in asthmatic patients after local provocation tests. Lancet 1983; i: 1406-1408.

20. Dent G, Giembycz MA, Wolf B, Rabe KF, Barnes PJ, Magnussen H. Identification of PDE III and PDE IV isoenzymes of cAMP PDE in human alveolar macrophages. Am Rev Respir Dis 1993; 147: A184.

21. Tenor H, Hatzelmann A, Kupferschmidt R, et al. Cyclic nucleotide phosphodiesterase isoenzyme activities in human alveolar macrophages. Clin Exp Allergy 1995; 25: 625-633.

22. Elliott KFR, Leonhard EJ. Interactions of formylmethionyl-leucyl-phenylalanine, adenosine and phosphodiesterase inhibitors in human monocytes. Effects on superoxide release, inositol phosphates and cAMP. FEBS Lett 1989; 254: 94-98.

23. Torphy TJ, Zhou H, Cieslinski LB. Stimulation of beta adrenoceptors in a human monocyte cell line (U937) upregulates cyclic AMP-specific phosphodiesterase activity. J Pharmacol Exp Ther 1992; 263: 1195-1205.

24. Chan SC, Reifsnyder D, Beavo JA, Hanifin JM. Immunochemical characterization of the distinct monocyte cyclic AMP phosphodiesterase from patients with atopic dermatitis. J Allergy Clin Immunol 1993; 91: 1179-1188.

25. Barnes PJ. Cyclic nucleotides and phosphodiesterases and airway function. Eur Respir J 1995; 8: 457-462.

26. Butler J, Chan SC, Stevens S, Hanifin M. Increased histamine release associated with elevated cAMP phosphodiesterase activity in atopic dermatitis. J Allergy Clin Immunol 1983; 71: 490-497.

27. Grewe SR, Chan SC, Hanifin JM. Elevated leukocyte cyclic AMP phosphodiesterase in atopic disease: a possible mechanism for cAMP-agonist hyperresponsiveness. $J$ Allergy Clin Immunol 1982; 70: 452-457.

28. Holden CA, Chan SC, Hanifin JM. Monocyte localization of elevated cAMP phosphodiesterase activity in atopic dermatitis. J Invest Dermatol 1986; 87: 372-376.

29. Beusenberg FD, Adolfs MJP, Van Schaik A, Van Amsterdam JGC, Bonta IL. Antigen challenge modifies the cyclic AMP response of inflammatory mediators and $\beta$-adrenergic drugs in alveolar macrophages. Eur J Pharmacol 1989; 174: 33-41.

30. Banner KH, Moriggi E, Da Ros B, Schioppacassi G, Semeraro C, Page CP. The effect of selective phosphodiesterase 3 and 4 isoenzyme inhibitors and established antiasthma drugs on inflammatory cell activation. $\mathrm{Br} J$ Pharmacol 1996; 119: 1255-1261.

31. Lagente V, Pruniaux MP, Junien JL, Moodley I. Modulation of cytokine-induced eosinophil infiltration by phosphodiesterase inhibitors. Am J Respir Crit Care Med 1995; 151: $1720-1724$. 